Jurnal Perikanan (2018) Volume 8. No. 1.: 55-64

\title{
PEMANFAATAN LIMBAH BUDIDAYA IKAN UNTUK PENINGKATAN PERTUMBUHAN BIOMASSA CACING SUTRA (Tubifex $\mathrm{sp.)}$
}

\section{FISH FARMING WASTE UTILIZATON FOR INCREASING SLUDGE WORM (Tubifex sp.) BIOMASS GROWTH}

\author{
Putu Pande Nico Ardana ${ }^{\left.{ }^{*}\right)}$, Zaenal Abidin ${ }^{1)}$, Nanda Diniarti ${ }^{1)}$ \\ ${ }^{1)}$ Program Studi Budidaya Perairan, Universitas Mataram \\ Jl. Pendidikan No. 37 Mataram, NTB
}

\begin{abstract}
Abstrak
Penelitian ini bertujuan untuk mengetahui peningkatan biomassa cacing sutra yang dikultur menggunakan limbah budidaya ikan lele, mas, dan nila, serta menghitung kemampuan cacing sutra untuk mereduksibahan organik di air. Pemeliharaan cacing sutra dilaksanakan di kolam pemeliharaan ikan di Desa Sokong, Kecamatan Tanjung,Kabupaten Lombok Utara sedangkan analisa kualitas air dilakukan di Laboratorium Budidaya Perairan Universitas Mataram. Penelitian menggunakan metode eksperimental dengan Rancangan Acak Lengkap dengan 3 perlakuan media yaitu feses ikan lele, feses ikan mas, dan feses ikan nila dengan biomassa cacing sutra tertinggi diperoleh pada penggunaan feses ikan lele yaitu $712,7 \mathrm{~g} / \mathrm{m}^{2}$. Cacing sutra memiliki kemampuan untuk mereduksi TOM dan $\mathrm{NH}_{3}$ di air. Hal terlihat dari adanya penurunan selisih konsentrasi TOM dan $\mathrm{NH}_{3}$ pada air yang digunakan sebelum dan selama pemeliharaan cacing sutra berlangsung.
\end{abstract}

Kata kunci : limbah budidaya ikan, pertumbuhan biomassa, $\mathrm{TOM}, \mathrm{NH}_{3}$, Tubifex $\mathrm{sp}$.

\begin{abstract}
The aims of the research were to evaluate the biomass growth of sludge worms (Tubifex sp.) which were cultivated by using waste from fish rearing and to calculate the ability of sludge worm to reduce total organic matter (TOM). The worms were cultivated in private fish rearing facility in Sokong, District of Tanjung, North Lombok, West Nusa Tenggara. The experiment was conducted by using Completely Randomized Design. The wastes, which were tested, were feces of catfish, carp, and tilapia with three replications. The result showed that biomass of sludge worms cultivating in catfish waste media reached the peak on the 45th day, while in carp and tilapia waste media, the biomass peaks were resulted on the 60th day. The highest biomass of sludge worms was obtained from cultivation in catfish waste media by $712,7 \mathrm{~g} / \mathrm{m}^{2}$. In addtion, the sludge worms had ability to reduce TOM and $\mathrm{NH}_{3}$ in water. It was proved by the reduction of TOM and $\mathrm{NH}_{3}$ concentration in the water used in rearing the worms.
\end{abstract}

Keywords : aquaculture waste, biomass growth, $\mathrm{TOM}, \mathrm{NH}_{3}$, Tubifex sp.

\section{Pendahuluan}

Kegiatan budidaya perikanan di
Indonesia setiap tahunnya mengalami perkembangan terutama dari sistem budidaya yang digunakan. Sistem budidaya yang banyak digunakan pada saat ini yaitu sistem budidaya intensif, sistem ini menggunakan budidaya ikan dengan kepadatan tinggi dan pemberian pakan buatan dengan protein tinggi. Dengan

*email korespondensi: kunikakul@gmail.com peningkatan kepadatan dan pemberian pakan berprotein tinggi menyebabkan penurunan kadar oksigen terlarut dan peningkatan limbah budidaya yang berasal dari sisa pakan, feses, dan ekskresi ammonia (Shafrudin dkk., 2006).

Peningkatan limbah di media budidaya dapat menurunkan kualitas perairan dan mengganggu keberlangsungan hidup ikan budidaya, namun apabila limbah tersebut dibuang langsung ke sungai maka dapat merusak 
kualitas air di sungai tersebut. Sehingga perlu dilakukan pengelolaan limbah budidaya. Air limbah budidaya yang mengandung banyak bahan organik akan dimanfaatkan oleh organisme dekomposer sebagai nutrient untuk pertumbuhan. Prinsip dari sistem ini yaitu memanfaatkan organisme dekomposer untuk mengurangi limbah di perairan pada budidaya sistem resirkulasi (Effendi dkk., 2015).

Salah satu biota yang dapat digunakan dalam proses bioremediasi yaitu cacing sutra (Tubifex sp.). Penelitian tentang cacing sutra dengan menggunakan limbah telah banyak dilakukan seperti limbah ampas tahu, limbah ikan, susu afkir, kotoran ayam, bungkil kelapa sawit. Pardiansyah dkk., 2014 yang meneliti tentang budidaya cacing sutra dengan limbah lele sistem bioflok dapat meningkatkan biomassa cacing sutra sampai $0,97 \mathrm{~kg} / \mathrm{m}^{2}$. Menurut Supriono dkk. (2015) cacing sutra dapat hidup pada perairan yang memiliki kandungan bahan-bahan organik yang tinggi dan dapat beradaptasi pada perairan dengan kadar DO yang rendah.

Cacing sutra merupakan pakan alami yang banyak digunaka oleh pembudidaya ikan terutama pada saat pembenihan ikan sehingga cacing sutra memiliki potensi untuk dikembangkan. Cacing ini memiliki kandungan nutrisi berupa protein $59 \%$, lemak $9 \%$, dan serat 0,01\% (Mohanta dan Subramanian, 2002), sehingga baik untuk pertumbuhan benih ikan. Menurut Suprayudi dkk. (2013) bahwa cacing sutra dapat diberikan setelah pemberian artemia di kegiatan pembenihan.

Potensi limbah budidaya dari ikan tertentu untuk mendukung kegiatan budidaya cacing sutra berbeda-beda, karena setiap ikan memiiki tingkat efisiensi pakan yang berbeda sehingga kandungan nutrisi dan jumlah limbah yang dihasilkan juga berbeda. Oleh karena itu penelitian ini dilakukan dengan tujuan untuk mengetahui pertumbuhan biomassa cacing sutra yang dipelihara pada media limbah pemeliharaan/feces ikan lele, nila, dan mas. Selain itu, penelitian ini juga bertujuan untuk mengetahui kemampuan cacing sutra untuk menurunkan kandungan bahan organik yang terlarut dalam air.

\section{Metode Penelitian}

Penelitian dilakukan selama 60 hari mulai dari September sampai November 2017. Penelitian dilaksanakan di unit pemeliharaan ikan mandiri yang terletak di Desa Sokong, Kecamatan Tanjung, Kabupaten Lombok Utara.

Penelitiandilaksanakan dengan metode eksperimental dan dirancang menggunakan rancangan acak lengkap dengan 3 perlakuan dan 3 kali ulangan. Perlakuan yang digunakan adalah berbagai jenis limbah budidaya yang digunakan sebagai media yaitu : limbah/feses lele, nila, dan mas.

\section{Budidaya ikan}

Kolam yang digunakan dalam pemeliharaan ikan lele, nila dan mas masingmasing berbentuk persegi panjang dengan ukuran panjang 1,6 x1 x 0,6 m. Air kolam diresirkulasi dan mengalir pada pipa talang dengan panjang 2,5 $\mathrm{m}$ sebagai tempat mengumpulkan feses ikan. Padat penebaran ikan adalah 160 ekor untuk setiap unit kolam. Ukuran ikan yang digunakan memiliki berat yang sama yaitu 10-20 gram/ekor. Ikan dipelihara selama 60 hari dan diberikan pakan dengan dosis 3-5\% dari bobot total ikan, dengan frekuensi pemberian pakan 2 kali sehari.

\section{Budidaya cacing sutra}

Pemeliharaan cacing sutra menggunakan

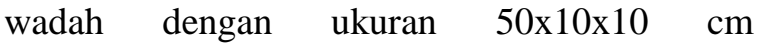
menggunakan sistem resirkulasi. Limbah budidaya ikan diberikan sebagai media pemeliharaan sesuai perlakuan dengan dosis 50 gr dalam berat kering untuk setiap wadah pemeliharaan cacing sutra. Jumlah cacing sutra yang digunakan dalam penebaran awal pada setiap wadah adalah $7 \mathrm{gr} /$ wadah budidaya. Setelah cacing ditebar, selanjutnya air diresirkulasi dengan debit air 0,5 $1 /$ menit menggunakan pompa dari wadah penampungan air pemeliharaan cacing sutra. Pemberian feses ulang dilakukan setiap 10 hari sekali dengan dosis feses yang diberikan 25 gr/wadah budidaya cacing. 


\section{Pengumpulan dan Analisis Data}

Sampling biomassa cacing sutra dilakukan pada hari ke $15,30,45$, dan 60 setelah penebaran awal cacing sutra. Seelah dilakukan sampling maka dilakukan perhitungan biomassa dengan rumus biomassa $=(\mathrm{Lo} / \mathrm{Li}) \times \mathrm{Bi}$, dimana Lo $=$ Luas media pemeliharaan cacing, $\mathrm{Li}=$ Luas sampel, $\mathrm{Bi}=$ Biomassa cacing pada sampel.

Parameter kualitas air yang diukur meliputi TOM (Total Organic Metter), $\mathrm{NH}_{3}, \mathrm{pH}$, DO, dan suhu. Pengukuran kualitas air dilakukan sebelum pergantian air dan setelah pergantian air media budidaya cacing yaitu pada hari ke-1, 15, 30, 45 dan 60, untuk hari ke-1 dilakukan pengukuran TOM dan $\mathrm{NH}_{3}$ setelah pergantian air masing masing dengan menggunakan metode titrasi dan spectrofotometer.

Analisis data dilakukan menggunakan ANOVA dengan selang kepercayaan 95\% dan diuji lanjut menggunakan LSD untuk melihat perbedaan setiap perlakuan.

\section{Hasil}

\section{Uji protein feses ikan}

Sebelum digunakan sebagai media budidaya cacing sutra maka dilakukan uji kadar protein terhadap masing-masing feses ikan. Hasil uji kadar protein feses ikan dapat dilihat pada Tabel 1.

Tabel 1. Hasil uji kadar protein dan air

\begin{tabular}{llll}
\hline Feses ikan & Kadar air $(\%)$ & $\begin{array}{l}\text { Kadar protein basah } \\
(\%)\end{array}$ & Kadar protein kering $(\%)$ \\
\hline Lele & 81,292 & 4,1216 & 22,03 \\
Mas & 82,6146 & 3,7771 & 21,73 \\
Nila & 84,1218 & 3,1497 & 19,84 \\
\hline
\end{tabular}

\section{Biomassa cacing sutra}

Pemeliharaan cacing sutra selama 60 hari menggunakan feses ikan lele, mas, nila sebagai media budidaya cacing, menghasilkan biomassa cacing sutra, dapat dilihat pada Grafik 1.

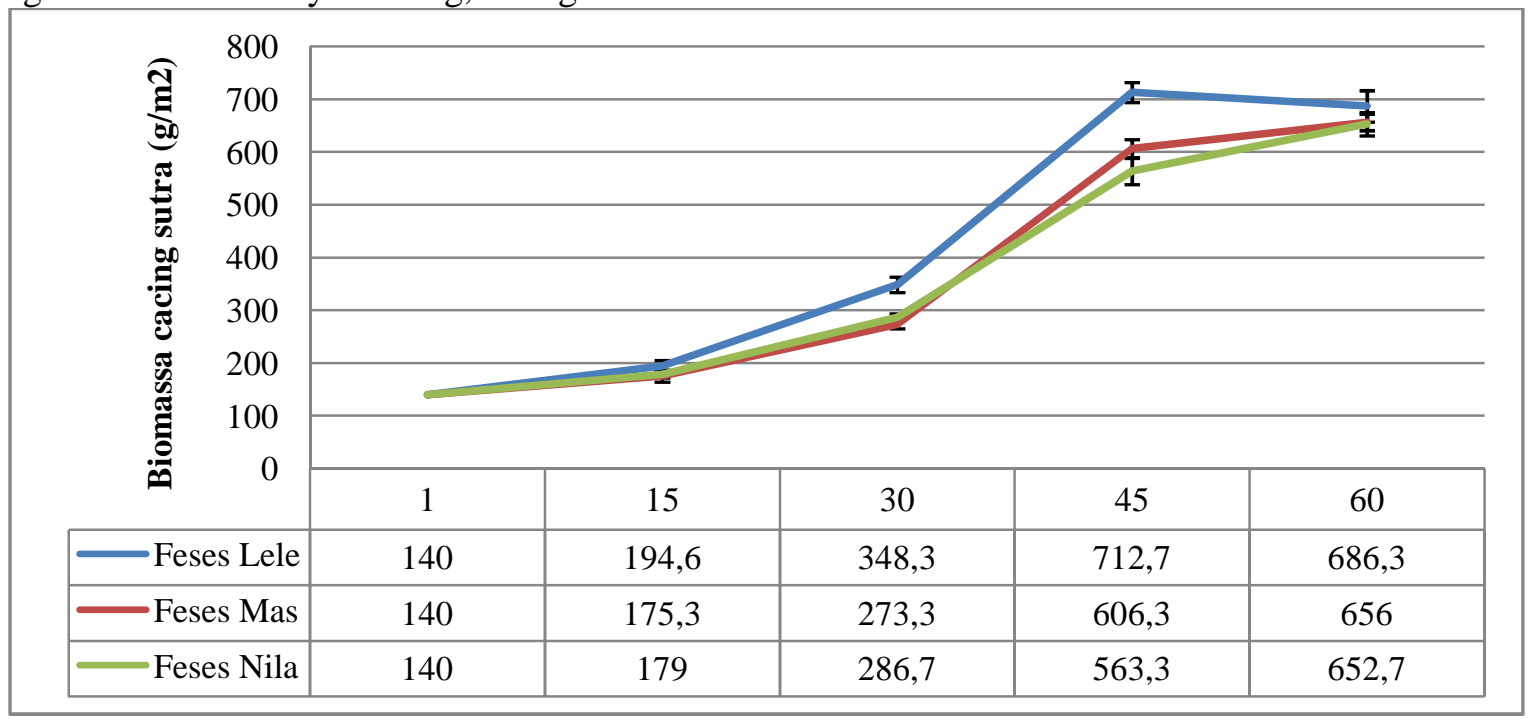

Grafik 1. Peningkatan biomassa cacing sutra

Dari Grafik 1 diketahui bahwa cacing sutra mengalami pertumbuhan biomassa dalam pemeliharaan selama 60 hari. Pertumbuhan biomassa tertinggi yaitu pada penggunaan feses ikan lele yang mencapai puncak biomassa pada hari ke 45 yaitu 712,7 $\mathrm{g} / \mathrm{m}^{2}$, sedangkan penggunaan feses ikan mas dan nila mencapai puncak bioassa pada hari ke-60 
yaitu mas $656 \mathrm{~g} / \mathrm{m}^{2}$ dan nila $652,7 \mathrm{~g} / \mathrm{m}^{2}$. Biomassa cacing sutra dengan penggunaan feses ikan lele mengalami penurunan pada hari ke 60 , dimana biomassa hari ke 60 menjadi $686,3 \mathrm{~g} / \mathrm{m}^{2}$. Setelah dilakukan analisis data menggunakan ANOVA, maka didapatkan hasi yang dapat dilihat pada Tabel 2 .
Pada Tabel 2 diketahui bahwa biomassa cacing sutra yang dipelihara pada media budidaya yang berbeda yaitu feses lele, mas dan nila mengalami perbedaan $(P<0,05)$ pada hari ke 30 dan 45 sedangkan pada hari ke 15 dan 60 tidak ada perbedaan $(P>0,05)$.

Tabel 2. Hasil uji ANOVA biomassa cacing sutra

\begin{tabular}{|c|c|c|c|c|}
\hline \multirow[t]{2}{*}{ Media } & \multicolumn{4}{|c|}{ Biomassa cacing sutra } \\
\hline & Hari ke $15^{\mathrm{ns}}$ & Hari ke $30^{\mathrm{s}}$ & Hari ke $45^{\mathrm{s}}$ & Hari ke $60^{\mathrm{ns}}$ \\
\hline Feses Lele & $194,6 \pm 10,69$ & $348,3 \pm 14,47^{\mathrm{a}}$ & $712,7 \pm 19,01^{\mathrm{a}}$ & $686,3 \pm 29,90$ \\
\hline Feses Mas & $175,3 \pm 11,24$ & $286,7 \pm 8,02^{b}$ & $606,3 \pm 16,92^{b}$ & $656 \pm 16,72$ \\
\hline Feses Nila & $179 \pm 7,0$ & $273,3 \pm 7,10^{b}$ & $563,3 \pm 24,91^{\mathrm{c}}$ & $652,7 \pm 22,19$ \\
\hline
\end{tabular}

Keterangan: $\quad$ Subscript yang berbeda pada kolom yang sama menunjukan adanya perbedaan pada setiap perlakuan $(P<0,05)$; (ns) non-signifikan $(P>0,05)$; (s) signifikan $(P<0,05)$.

Pada hari ke 30, biomassa cacing sutra dengan media pemeliharaan feses lele lebih tinggi dibandingkan dengan biomassa cacing sutra dengan media pemeliharaan feses mas dan nila $(P<0,05)$, sedangkan biomassa cacing sutra dengan media pemeliharaan feses ikan mas dan nila tidak berbeda $(P>0,05)$.Hari ke 45 , biomassa cacing sutra dengan media pemeliharaan feses lele lebih tinggi dibandingkan dengan biomassa cacing sutra dengan media pemeliharaan feses ikan mas dan nila $(\mathrm{P}<0,05)$, serta biomassa cacing sutra dengan media pemeliharaan feses ikan mas lebih tinggi dibandingkan biomassa cacing sutra dengan media pemeliharaan feses nila. Hasil pengukuran laju pertumbumbuhan biomassa harian cacing sutra dapat dilihat pada Tabel 3.

Tabel 3. Laju pertumbuhan biomassa harian.

\begin{tabular}{|c|c|c|c|c|}
\hline \multirow[t]{2}{*}{ Media } & \multicolumn{4}{|c|}{ Laju Pertumbuhan Biomassa Harian (\%/hari) } \\
\hline & Hari ke $1-15^{\mathrm{ns}}$ & Hari ke $15-30^{\mathrm{s}}$ & Hari ke $30-45^{\mathrm{s}}$ & Hari ke $45-60{ }^{\text {sig }}$ \\
\hline Feses Lele & $2,2 \pm 0,33$ & $3,9 \pm 0,23^{\mathrm{a}}$ & $4,8 \pm 0,43^{\mathrm{ab}}$ & $-0,3 \pm 0,28^{b}$ \\
\hline Feses Mas & $1,5 \pm 0,43$ & $3,0 \pm 0,53^{b}$ & $5,3 \pm 0,31^{\text {a }}$ & $0,5 \pm 0,34^{\mathrm{a}}$ \\
\hline Feses Nila & $1,6 \pm 0,26$ & $3,1 \pm 0,35^{\mathrm{ab}}$ & $4,5 \pm 0,45^{b}$ & $1,0 \pm 0,30^{\mathrm{a}}$ \\
\hline
\end{tabular}

Dari Tabel 3, diketahui bahwa laju pertumbuhan biomassa harian cacing sutra menggunakan media feses ikan lele, mas, dan nila, menghasilkan nilai biomassa harian yang berbeda-beda. Pada hari ke 15-30 laju pertumbuhan biomassa harian cacing sutra tertinggi pada penggunaan media feses lele dan tidak berbedanyata degan biomassa harian cacing sutra menggunakan media feses ikan mas $(P>0,05)$ tetapi berbeda dengan biomassa harian cacing sutra menggunakan media feses nila
$(P<0,05)$, sedangkan biomassa harian cacing sutra yang menggunakan meia feses mas dan feses nila tidak mengalami perbedaan $(P>0,05)$. Pada hari ke 30-45 laju pertumbuhan biomassa harian cacing sutra tertinggi pada penggunaan media feses mas dan tidak berbedanyata degan biomassa harian cacing sutra menggunakan media feses ikan lele $(P>0,05)$ tetapi berbeda dengan biomassa harian cacing sutra menggunakan media feses nila $(P<0,05)$, sedangkan biomassa harian cacing sutra yang 
menggunakan meia feses lele dan feses nila tidak mengalami perbedaan $(P>0,05)$. Laju pertumbuhan biomassa harian cacing sutra pada hari ke 45-60 menunjukan bahwa biomassa harian cacing sutra yang menggunakan media feses ikan mas dan nila tidak mengalami perbedaan $(P>0,05)$, tetapi berbeda dengan biomassa harian yang menggunakan media feses lele $(P<0,05)$.

\section{Total Organic Metter (TOM)}

Pengukuran sampel air TOM selama pemeliharaan cacing sutra dilakukan setelah pergantian air dan 15 hari setelah di resirkulasi pada media budidaya cacing sutra. Pergantian air lama dengan air baru serta pengambilan sampl air uji TOM dilakukan pada hari ke 1, 15, 30, dan 45 sedangkan pengambilan sampel air yang telah diresirkulasi pada media budidaya cacing sutra untuk uji TOM yaitu hari ke 15,30,45, dan 60.

Hasil pengukuran TOM dapat dilihat pada Grafik 2.Pada Grafik 2, diketahui bahwa nilai TOM setelah pergantian air dan setelah diresirkulasi pada media budidaya cacing sutra selama 15 hari terdapat selisih yang cukup tinggi setelah dilakukan pengambilan sampel sebanyak 4 kali.Kisaran selisih penurunan nilai TOM setelah pergantian air dan setelah diresirkulasi selama15 hari pada penggunaan media budidaya feses lele yaitu, 13,272 sampai 20,271 mg/l, pada media budidaya feses ikan mas yaitu, 11,529 sampai $19,256 \mathrm{mg} / \mathrm{l}$, sedangkan pada media budidaya feses ikan nila selisihnya yaitu, 8,690 sampai $18,867 \mathrm{mg} / \mathrm{l}$.

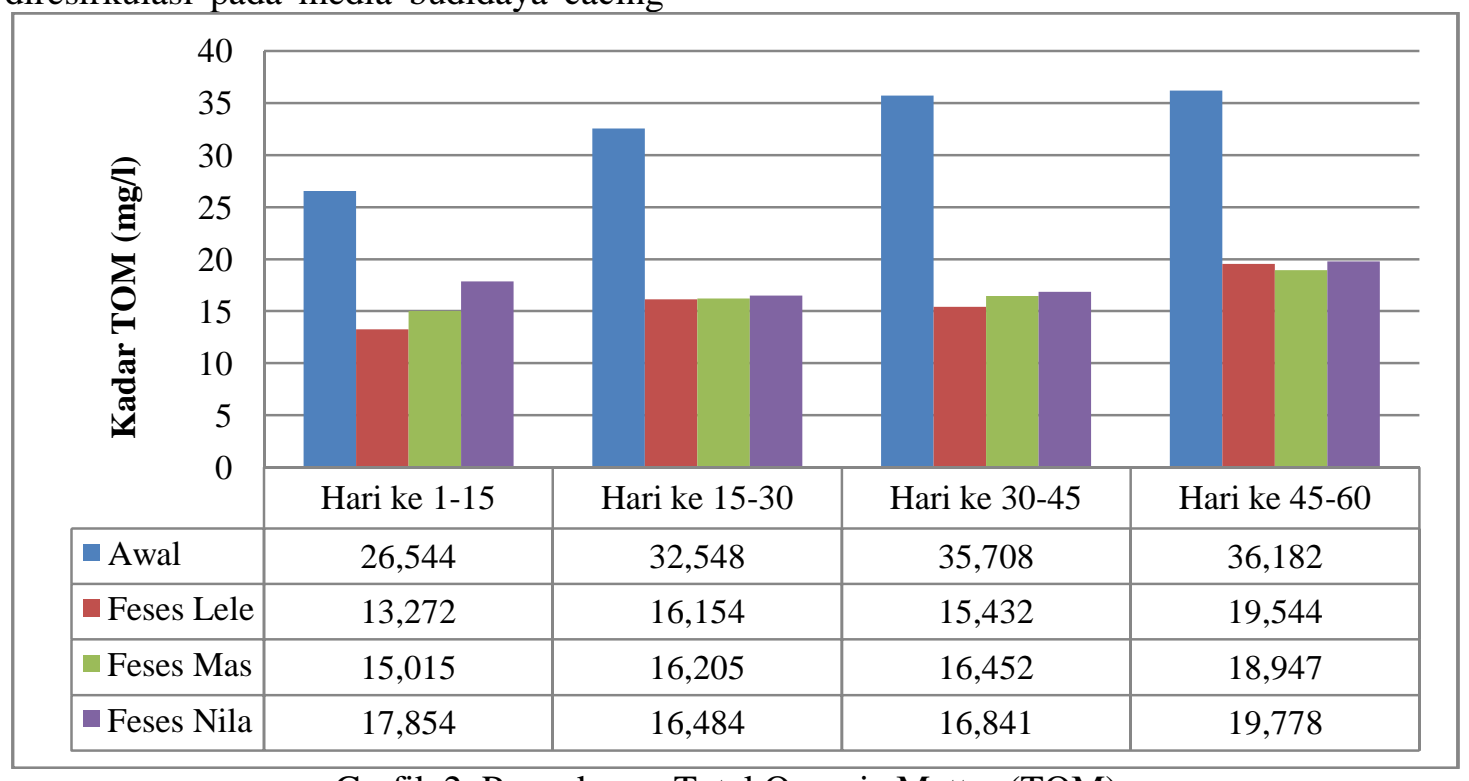

Grafik 2. Pengukuran Total Organic Metter (TOM)

\section{Ammonia $\left(\mathrm{NH}_{3}\right)$}

Pengukuran sampel air ammonia selama pemeliharaan cacing sutra dilakukan setelah pergantian air dan 15 hari setelah di resirkulasi pada media budidaya cacing sutra. Pergantian air lama dengan air baru serta pengambilan sampl air uji $\mathrm{NH}_{3}$ dilakukan pada hari ke 1, 15, 30, dan 45 sedangkan pengambilan sampel air yang telah di resirkulasi pada media budidaya cacing sutra untuk uji $\mathrm{NH}_{3}$ yaitu hari ke 15,30,45, dan 60. Hasil pengukuran $\mathrm{NH}_{3}$ dapat dilihat pada Grafik 3.Pada Grafik 3, diketahui bahwa nilai
$\mathrm{NH}_{3}$ setelah pergantian air dan setelah diresirkulasi pada media budidaya cacing sutra selama 15 hari terdapat selisih yang cukup tinggi setelah dilakukan pengambilan sampel sebanyak 4 kali. Kisaran selisih penurunan nilai $\mathrm{NH}_{3}$ setelah pergantian air dan setelah diresirkulasi selama15 hari pada penggunaan media budidaya feses lele yaitu, 1,1044 sampai 1,7496 mg/l, pada media budidaya feses ikan mas yaitu, 1,1127 sampai $1,7278 \mathrm{mg} / \mathrm{l}$, sedangkan pada media budidaya feses ikan nila selisihnya yaitu, 0,9658 sampai $1,6877 \mathrm{mg} / \mathrm{l}$. 


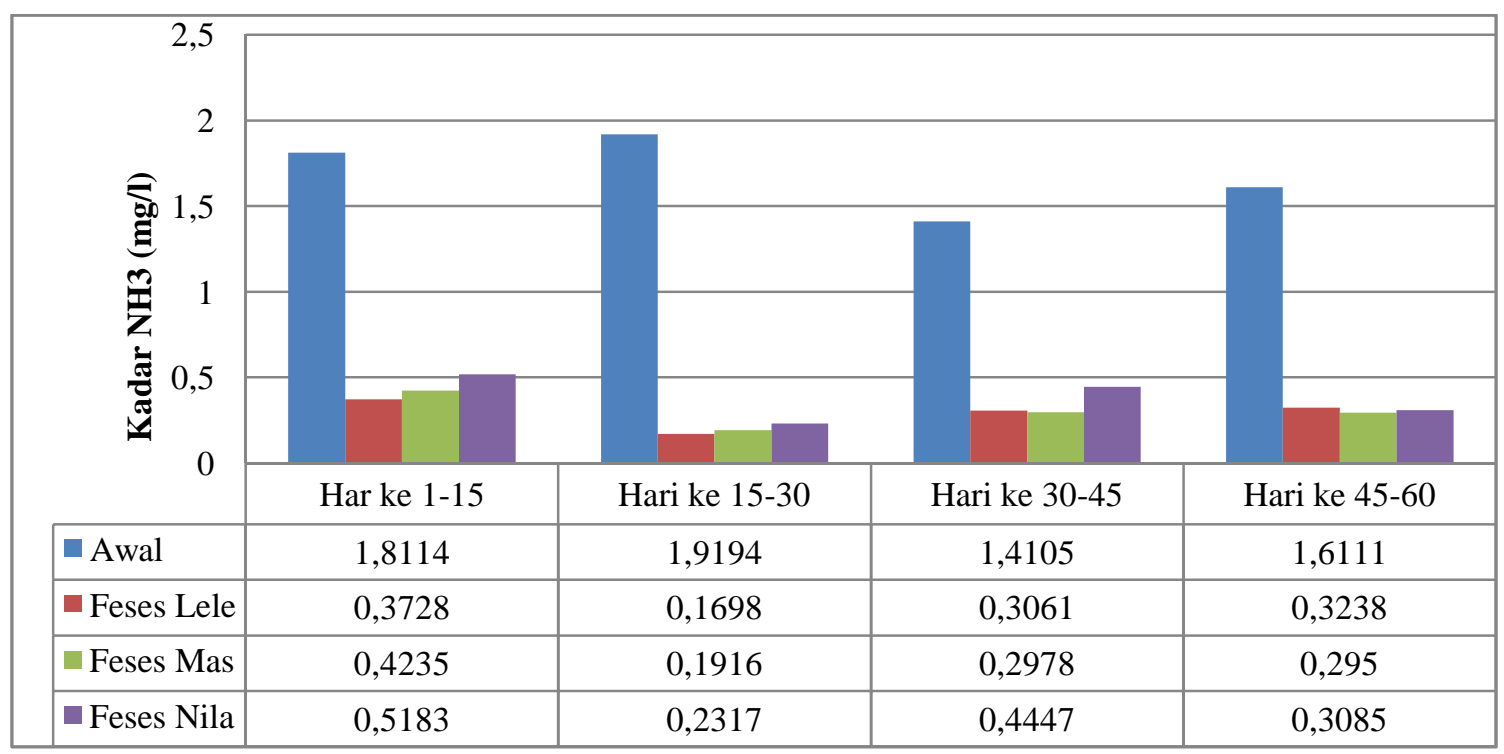

Grafik 3. Penurunan kadar ammonia $\left(\mathrm{NH}_{3}\right)$

\section{Kualitas air}

Pengukuran kualitas air dilakukan sebanyak 4 kali yaitu pada hari ke 1, 14,29, 44, dan 59 dan diperoleh kisaran kialitas air seerti pada Tabel berikut. Hasil pengukuran kualitas air dapat dilihat pada Tabel 4.

Tabel 4. Kualitas air budidaya cacing sutra

\begin{tabular}{llll}
\hline Parameter & Hasil pengukuran & Baku mutu (Efendi, 2017) & Keterangan \\
\hline DO $(\mathrm{mg} / \mathrm{l})$ & $2,3-3,1$ & $2,5-7$ & Baik \\
Suhu $\left({ }^{\circ} \mathrm{C}\right)$ & $24-26$ & $25-28$ & Kurang baik \\
$\mathrm{pH}$ & $6,3-6,7$ & $5,5-8,0$ & Baik \\
Debit air (liter/menit) & 0,5 & 0,5 & Baik \\
\hline
\end{tabular}

\section{Pembahasan}

\section{Protein feses ikan}

Peningkatan biomassa cacing sutra juga dapat dikarenakan oleh feses ikan masih memiliki kandungan nutrisi berupa protein yang dapat dimanfaatkan oleh cacing sutra. Dimana kandungan protein masing-masing feses yang digunakan yaitu lele $22,03 \%$, mas $21,73 \%$, dan nila $19,84 \%$. Adanya kandungan protein pada feses ikan ini dikarenakan ikan tidak dapat memanfaatkan $100 \%$ nutrisi dari pakan yang di berikan sehingga feses yang di hasilkan masih memiliki kandungan protein yang masih dapat dimanfaatkan. Kandungan protein feses ikan mengalami perbedaan walaupun pakan yang diberikan dengan jenis yang sama dan dosis yang sama juga. Kemungkinan perbedaan kandungan protein ini dikarenakan oleh kemampuan dari masing-masing ikan untuk memanfaatkan pakan yang diberikan berbeda. Seperti ikan lele yang dapat memanfaatkan pakan sebesar $44,63 \%$ dari total yang diberikan (Amalia dkk., 2013), Ikan mas 57,70\% (Pratama dkk., 2015), Ikan nila 83,47\% (Mulyani dkk., 2014). Semakin baik kemampuan ikan untuk memanfaatkan pakan maka semakin sedikit limbah yang di buang ke perairan, inilah yang menyebabkan ikan lele memiliki kandungan protein feses yang lebih tinggi dibandingkan ikan mas dan nila karena kemampuannya untuk memanfaatkan pakan yang rendah.

\section{Biomassa cacing sutra}

Adanya peningkatan biomassa selama pemeliharaan cacing sutra membuktikan bahwa cacing sutra dapat memanfaatkan feses ikan sebagai pakan untuk keberlangsungan hidupnya 
dan perkembangbiakannya. Hal ini dikarenaan partikel feses ikan berukuran kecil dan masih memiliki kandungan nutrisi untuk cacing sutra. Karena sifat cacing sutra sendiri yang mencari makan dan hidup pada daerah perairan yang memiliki kandungan nutrisi yang tinggi. Menurut (Khairuman, 2008) untuk mendukung kehidupan cacing sutra yaitu dasar perairan berlumpur, banyak mengandung bahan organik, air tenang namun tetap mengalir serta perairan yang sejuk.

Pada hari ke 1-15, peningkatan biomassa cacing sutra termasuk rendah bila dibandingkan dengan biomassa hari selanjutnya yaitu hari 30, 45, dan 60. Rendahnya peningkatan biomassa pada awal pemeliharaan ini dikarenakan cacing sutra harus beradaptasi dengan ligkungan baru yang berbeda dengan lingkungan awalnya. Pada pernyataan (Pardiansyah dkk., 2014), menyatakan bahwa biomassa cacing sutra mengalami penurunan pada hari ke 10 dan meningkat pada hari ke 15 sampai akhir penelitian.

Tingginya kandungan protein pada feses ikan sangat berpengaruh terhadap peningkatan biomassa cacing sutra. Dimana pada penggunaan feses ikan lele memberikan hasil peningkatan biomassa tertinggi, sedangkan penggunaan feses ikan nila memberikan hasil peningkatan biomassa terendah. Walaupun memiliki peningkaan biomassa tertinggi, tetapi pada penggunaan feses ikan lele mengalami penurunan pertumbuhan pada hari ke 60 .

Penurunan biomassa perlakuan menggunakan feses ikan lele pada hari ke 60 kemungkinan dikarenakan kemampuan media budidaya sudah tidak dapat memenuhi kebutuhan pakan dari cacing sutra itu sendiri, oleh karena itu banyak cacing sutra yang mengalami kematian sehingga biomassa cacing sutra pada penggunaan feses ikan lele mengalami penurunan pada hari ke 60. Selain kurangnya pakan, penurunan biomassa kemungkinan disebabkan karena individu tua telah mencapai fase kematian. Hal ini sesuai dengan pernyataan (Shafrudin dkk., 2005) yang menyatakan bahwa penurunan biomassa cacing sutra dari hari 20-50 dikarenakan banyaknya individu tua yang mati sedangkan individu muda belum mencapai fase reproduksi, karena waktu yang dibutuhkan cacing sutra dari telur sampai menjadi indukan yaitu 57 hari.

Karena terjadinya penurunan biomassa dan perlambatan pertumbuhan biomassa pada hari ke 60, maka pemanenan cacing sutra disarankan yaitu pada hari ke 45 karena puncak pertumbuhan biomassa terjadi pada hari tersebut. Nilai biomassa total yang didapatkan pada penelitian setelah pemeliharaan selama 60 hari terbilang rendah karena biomassa tertinggi pada penggunaan feses ikan lele pada hari ke 45 yaitu $712,7 \mathrm{~g} / \mathrm{m}^{2}$ hanya menghasilkan 686,3 $\mathrm{g} / \mathrm{m}^{2}$. Nilai biomassa yang diperoleh ini lebih rendah dibandingkan dengan penelitian (Pardiansyah dkk.,2014) yang menggunakan limbah lele sistem bioflok memberikan nilai biomassa total $970 \mathrm{~g} / \mathrm{m}^{2}$ dalam waktu pemeliharaan 40 hari.

Rendahnya laju pertumbuhan biomassa harian pada hari ke 1-15 dikarenakan cacing sutra yang baru ditebar masih beradaptasi dengan lingkungan barunya. Pardiansyah (2014), menyatakan bahwa biomassa cacing sutra mengalami penurunan pada hari ke-10 dan mulai meningkat pada hari ke-15 sampai akhir penelitian hari ke-40. Laju pertumbuhan biomassa harian tertinggi pada setiap perlakuan penggunaan feses ikan lele, mas, dan nila yaitu pada hari ke 30-45, hal ini kemungkinan karena pada hari tersebut merupakan puncak pertumbuhan dari koloni cacing sutra. Kemungkinan tingginya pertumbuhan biomassa harian cacing sutra pada hari ke 30-45 dikarenakan banyak individu baru cacing sutra yang memasuki fase dewasa namun belum memasuki fase reproduksi, karena untuk mencapai fase reproduksi cacing sutra membutuhan waktu 57 hari (Gusrina, 2008 dalam Efemdi, 2013). Kemudian adanya penurunan pertumbuhan biomassa harian pada perlakuan feses lele pada hari ke 60 dikarenakan lebih banyak individu tua yang mati dibandingkan pertumbuhan individu muda, sehingga pertumbuhan biomassa harian cenderung menurun (Shafrudin dkk., 2005).

\section{Total organic metter (TOM)}

Cacing sutra memiliki peranan yang penting dalam mengurangi konsentrasi bahan organik di air. Peranan cacing sutra sendiri 
dalam mengurangi konsentrasi TOM karena cacing sutra dapat memanfaatkan bahan organik di perairan sebagai pakannya. Bahan organik yang dimanfaatkan cacing sutra yaiu yang tersuspensi dan mengendap di dasar perairan karena cacing sutra mencari makan di dasar perairan. Menurut (Putri dkk., 2014) menyatakan bahwa nilai TOM air yang tinggi dapat meningkatkan biomassa cacing sutra. TOM sendiri merupakan parameter yang menunjukkan tinggi atau rendahnya bahan organik yang ada di perairan, semakin tinggi nilai tom makan semakin tinggi kandungan bahan organik di perairan yang dapat menyebabkan rusaknya kualitas air.

Kadar nilai TOM setelah pergantian air masih dapat ditoleransi oleh cacing sutra kerena masih dalam kisaran yang cukup yaitu 26,544$36,182 \mathrm{mg} / \mathrm{l}$, dalam penelitian Pardiansyah (2014) nilai TOM pada air media budidaya cacing sutra dapat mencapai 64,97 - 108,04 $\mathrm{mg} / \mathrm{l}$. Setelah diresirkulasi pada media budidaya cacing sutra, nilai TOM semakin baik karena nilainya di bawah $20 \mathrm{mg} / \mathrm{l}$. Menurut (Effendi dkk., 2003) kadar TOM di air dikatakan baik apabila nilainya $<20 \mathrm{mg} / \mathrm{l}$ sedangkan nilai TOM dikatakan cukup apabila nilainya 20-40 mg/l. Penurunan kadar TOM ini menunjukan bahwa cacing sutra dapat digunakan sebagai biofilter dalam budidaya ikan air tawar dengan sistem resirkulasi, ataupun dapat digunakan sebagai pengelola limbah budidaya sebelum di buang ke perairan bebas.

Kisaran selisih penurunan nilai TOM pada setiap perlakuan dengan 4 kali pengukuran yaitu pada penggunaan media budidaya feses lele, 13,272 sampai $20,271 \mathrm{mg} / \mathrm{l}$, pada media budidaya feses ikan mas, 11,529 sampai 19,256 $\mathrm{mg} / \mathrm{l}$, sedangkan pada media budidaya feses ikan nila, 8,690 sampai $18,867 \mathrm{mg} / \mathrm{l}$. Pada penelitian (Nugroho dkk., 2014) dengan menggunakan ikan sapu-sapu dengan ukuran berbeda dapat mengurangi kadar TOM dengan selisih penurunan 26,19 sampai $50,03 \mathrm{mg} / \mathrm{l}$. Serta pada penelitian (Lestari dkk., 2013) yang menggunakan genteng pelastik bergelombang sebagai biofilter menghasilkan penurunan bahan organik dari 10,96 menjadi 5,586 mg/l. Selisih peurunan kadar TOM dalam julah \% yaitu perlakuan media feses ikan lele mencapai 50-
$56,77 \%$, media feses ikan mas 43,43-53,93\%, dan perlakuan media feses ikan nila 32,7$52,84 \%$.

Selisih penurunan nilai TOM pada hari ke 1-15 merupakan yang paling rendah bila dibandingkan pengukuran hari 15-30, 30-45, dan 45-60, ini kemungkinan dikarenakan biomassa cacing sutra pada awal penelitia masih rendah bila dibandingkan dengan hari selanjutnya sehingga kemampuan untuk memanfaatkan bahan organic di perairan juga masih rendah. Dalam penelitian (Putri dkk., 2014) semakin tinggi biomassa cacing maka semakin tinggi selisih penurunan nilai TOM. Penurunan nilai TOM pada hari ke 45-60 memiliki selisih yang rendah dibandingkan nilai pengukuran hari ke 15-30 dan 30-45, hal ini kemugkinan dikarenakan cacing sutra sebagian sudah memasuki fase tua sehingga kemampuan cacing sutra untuk memanfaatkan bahan organik menjadi berkurang.

\section{Ammonia $\left(\mathrm{NH}_{3}\right)$}

Konsentrasi $\mathrm{NH}_{3}$ di perairan tidak boleh melebihi batas yang dianjurkan karena dapat mengganggu kelangsungan hidup dari biota yang dipelihara. Pada penelitian ini kadar $\mathrm{NH}_{3}$ setelah pergantian air menggunakan air budidaya ikan sangat tinggi yaitu rata-rata mencapai $1,6881 \mathrm{mg} / \mathrm{l}$, tetapi setelah 15 hari dialiri pada media budidaya cacing sutra, kadar $\mathrm{NH}_{3}$ di air mengalami penurunan. Kisaran selisih penurunan kadar $\mathrm{NH}_{3}$ setelah pergantian air dan setelah diresirkulasi selama15 hari pada penggunaan media budidaya feses lele yaitu, 1,0644 sampai 1,6496 mg/l, pada media budidaya feses ikan mas yaitu, 1,1127 sampai $1,5762 \mathrm{mg} / \mathrm{l}$, sedangkan pada media budidaya feses ikan nila selisihnya yaitu, 0,9658 sampai $1,6877 \mathrm{mg} / \mathrm{l}$.

Dengan adanya penurunan kadar $\mathrm{NH}_{3}$ ini menunjukan bahwa cacing sutra dapat digunakan sebaga biofilter dalam kegiatan budidaya ikan air tawar. Dari hasil pengukuran nilai $\mathrm{NH}_{3}$ setelah 15 hari diresirkulasi pada media budidaya cacing sutra masih cukup tinggi yaitu pada media feses lele berkisar 0,1698$0,3728 \mathrm{mg} / \mathrm{l}$, media feses ikan mas berkisar 0,1916-0,4235 mg/l, dan pada media feses nila berkisar 0,2317-0,5183 mg/l. Jika dibandingkan 
dengan hasil penelitian (Pardiansyah dkk., 2014) yaitu 0,03-0,10 mg/l, makan kadar nilai $\mathrm{NH}_{3}$ masih cukup tinggi. Hal ini kemungkinan disebabkan karena rendahnya biomassa cacing sutra sehingga penurunan kadar $\mathrm{NH}_{3}$ di air tidak maksimal, sesuai dengan penelitian (Putri dkk., 2014) yang menyatakan semakin tinggi biomassa dan kelimpahan individu cacing sutra maka semakin tinggi juga penurunan kadar $\mathrm{NH}_{3}$. Selisih penurunan $\mathrm{NH}_{3}$ dalam jumlah $\%$ terbaik yaitu perlakuan media feses ikan lele 78,3-91,15 $\%$, dan diikuti perlakuan media feses ikan mas 78.9-90,02 \% , dan perlakuan media feses ikan nila $8,47-87,93 \%$.

$\mathrm{NH}_{3}$ di air berasal dari pemecahan nitrogen organik dan nitrogen anorganik yang terdapat dalam feses dan sisa budidaya ikan yang dilakukan oleh mikroba dan jamur yang dikenal dengan istilah amonifikasi (Effendi, 2004). Tingginya kandungan $\mathrm{NH}_{3}$ di suatu perairan dapat mengganggu kehidupan biota yang ada di dalamnya. Kadar $\mathrm{NH}_{3}$ pada kisaran 0,1-0,3 mg/l dapat menyebabkan keracunan pada ikan tertentu sedangkan kadar $\mathrm{NH}_{3}$ pada kisaran 0,6-3,0 mg/l dapat menyebabkan kematian pada ikan (Daelani, 2001). Cacing sutra merupakan salah satu biota yang dapat memanfaatkan bahan organik sebagai makanannya, sehingga dengan menggunakan cacing sutra sebaga biofilter maka dapat mengurangi kandungan $\mathrm{NH}_{3}$ yang ada di perairan. Seperti pada penelitian (Supriyono dkk., 2015) kelarutan ammonia paling renda yaitu 0,02-0,06 mg/l. Mekanismenya yaitu dengan cacing sutra memakan bahan organik berupa feses ikan maka kemungkinan untuk terjadi proses amonifikasi (perombakan bahan organik menjadi $\mathrm{NH}_{3}$ ) menjadi berkurang sehingga konsentrasi $\mathrm{NH}_{3}$ menjadi berkurang.

\section{Kualitas air}

Nila DO dan $\mathrm{pH}$ selama pemeliharaan cacing sutra masih dikatakan baik karena hasil pengukuran DO 2,3-3,2 $\mathrm{ppm}$ dan $\mathrm{pH}$ 6,3-6,7 sedangkan baku mutu kualitas air menurut (Effendi, 2017) yaitu DO 2,5-7 ppm dan pH 5,58. Untuk pengukuran suhu selama pemeliharaan cacing didapatkan hasil yaitu $24-26{ }^{\circ} \mathrm{C}$ sedangkan baku mutu suhu menurut (Effendi, 2017) suhu yang baik untuk cacing sutra yaitu $25-28^{\circ} \mathrm{C}$.
Dalam budidaya cacing sutra, kualitas air sangat memiliki peranan yang penting untuk keberlangsungan hidup dan pertumbuhan cacing sutra. Walaupun cacing sutra biasanya hidup pada perairan kotor dan memiliki kandungan bahan organic yang tinggi, tetapi untuk pertumbuhan yang optimal dalam budidaya maka faktor kualitas air sangan perlu diperhatikan. Salah satunya yaitu debit air yang tidak terlalu besar yaitu sekita $0,51 /$ menit, hal ini berkaitan dengan habitat cacing sutra yang menyukai perairan tenang tetapi airnya yang mengalir terus. Aliran air yang tenang menyebabkan bahan organic akan mengendap di perairan, sengankan apabila alirannya deras makan bahan organic akan terbawa oleh air.

\section{Kesimpulan}

Budidaya cacing sutra dapat menggunakan feses lele sebagai media budidaya dan lebih baik dibandingkan menggunakan media feses nila dan mas. Penggunaan feses lele sebagai media budidaya cacng sutra, menghasilkan biomassa cacing sutra tertinggi pada pemeliharaan 45 hari.

Cacing sutra memiliki kemampuan untuk memanfaatkan bahan organik sehingga dapat menurunkan nilai TOM dan $\mathrm{NH}_{3}$ di air.

\section{Daftar Pustaka}

Arief, M., Fitriani, N., Subekti, S. (2014) Pengaruh Pemberian Probiotik Berbeda Pada Pakan Komersial Terhadap Perumbuhan Dan Efisiensi Pakan Ikan Lele Sangkuriang (Clarias sp.) Jurnal Ilmiah Perikanan Dan Kelautan 6(1):4953.

Efendi, M.(2013). Beternak Cacing Sutra Cara Moderen. Jakarta. Penebar Swadaya.

Efendi, M., dan Tiyoso, A. (2017). Panen Cacing Sutra Setiap 6 Hari. Jakarta. Agro Media Pustaka.

Effendi, H., Utomo, B.A., Darmawangsa, G.M., Karo-karo, R.E. (2015). Fitoremediasi Limbah Budidaya Ikan Lele (Clarias sp.) Dengan Kangkung (Ipomoea aquatica) Dan Pakchoy (Brassica rapacbinensis) 
Dalam Sistem Resirkulasi. Jurnal Ecolab 9: 47-104.

Gunadi, B., dan Hafsaridewi, R. (2008). Pengendalian Limbah Amonia Budidaya Ikan Lele Dengan Sistem Heterotrofik Menuju Sistem Akuakultur Nirlimbah. Jurnal Riset Akuakultur 3 : 437-448.

Masrurotun, S., dan Johannes. (2014). Pengaruh Peambahan Kotoran Ayam, Silase Ikan, dan Tepung Tapioka Dalam Media Kultur Terhadap Biomassa, Populasi dan Kandungan Nutrisi Cacing Sutra (Tubifexsp.). Journal of Aquaculture Management and Thecnology 3(4):151157.

Mohanta, K. N., \&Subramanian, S. (2002). Effect of Diets With Protein From Different Sources on the Growth of Goldfish (Carassius auratus). The Israeli Journal of Aquaculture 3(54):1334-140.

Noviana, P., Subandiyono., Pinandoyo. (2014). Pengaruh Pemberian Probiotik Dalam Pakan Buatan Terhadap Tingkat Konsumsi Pakan Dan Pertumbuhan Ikan Nila (Oreochromis niloticus). Journal of Aquaculture Management and Thecnology 3:183-190.

Pardiansyah, D., Supriyono, E., Djokosetianto, D.( 2014). Evaluasi Budidaya Cacing Sutra yang Terintegrasi Dengan Budidaya Ikan Lele Sistem Bioflok. Jurnal Akuakultur Indonesia 1:28-35.

Pratama, M.A., Subandiyono., Pinandoyo. (2015). Pengaruh Berbagai Rasio E/P Pakan Berkadar Protein 30\% Terhadap Efisiensi Pemanfaatan Pakan dan Pertumbuhan Ikan Mas (Cyprinus carpio). Journal of Aquaculture Management and Thecnology. 4(4):74-81.
Putri, D.S., Supriyono, E., Djokosetiyanto, D. (2014). Pemanfaatan Kotoran Ayam Fermentasi Dan Limbah Budidaya Lele Pada Budidaya Cacing Sutra Dengan Sistem Resirkulasi. Jurnal Akuakultur Indonesia 13:132-139.

Shafrudin, D., Efiyanti, W., Widanami. (2005). Pemanfaatan ulang Limbah Organik dari Substrat Tubifes sp. di Alam. Jurnal Akuakultur Indonesia 4:97-102.

Shafrudin, D., Yuniarti, Setiawati, M. (2006). Pengaruh Kepadatan Benih Ikan Lele Dumbo (Clarias. sp) Terhadap Produksi Pada Sistem Budidaya Dengan Pengendalian Nitrogen Melalui Penambahan Tepung Terigu. Jurnal Akuakultur Indonesia 5(2):137-147.

SNI. (2005). Cara Uji Kadar Amonia dengan Spektrofotometer Secara Fenat. Badan Stadarisasi Nasional (BSN). 06-6989-30.

Sulistiyarto, B. (2016). Pemanfaatan Limbah Budidaya Ikan Lele Dumbo Sebagai Sumber Bahan Organik Untuk Memproduksi Bloodworm (Larva Chironomidae). Jurnal Ilmu Hewani Tropika 5(1):36-40.

Suprayudi, M.A., Ramadhan, R., Jusadi, D.(2013). Pemberian Pakan Buaan Untuk Larva Ikan Patin (Pangasionodon sp.) Pada Umur Berbeda. Jurnal Akuakultur Indonesia 2(12):193-200.

Supriyono, E., Pardiansyah, D., Putri, D.S., Djokosetianto, D. (2015). Perbandingan Jumlah Bak Budidaya Cacing Sutra (Tubificidae) Dengan Memanfaatkan Limbah Budidaya Ikan Lele (Clarias sp.) Sistem Intensif Terhadap Kualitas Air Ikan Lele Dan Produksi Cacing Sutra. Jurnal Depik. Vol : 1 No : 4. 